\title{
Synthesis and Catalytic Reactivity of Bis(amino)cyclopropenylidene Carbene-Borane Adducts
}

\author{
Blake S. N. Huchenski ${ }^{\dagger}$, Matt R. Adams ${ }^{\dagger}$, Robert McDonald ${ }^{\ddagger}$, Michael J. Ferguson ${ }^{\ddagger}$, \\ Alexander W. H. Speed*† \\ $\dagger$ Department of Chemistry, Dalhousie University, 6274 Coburg Road, P.O. Box 15000, Halifax, Nova \\ Scotia, Canada B3H 4R2 \\ \$ X-ray Crystallography Laboratory, Department of Chemistry, University of Alberta, Edmonton, Alberta, \\ Canada T6G 2G2
}

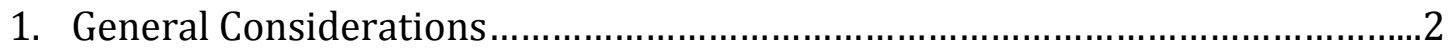

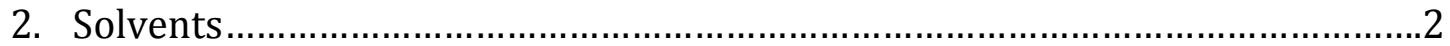

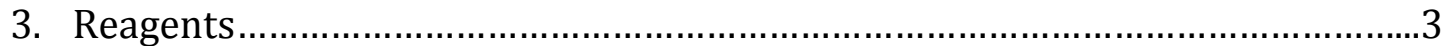

4. Crystallographic Solution and Refinement Details......................................... 4

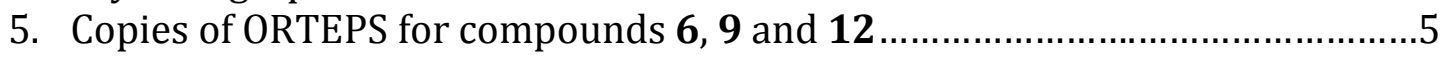

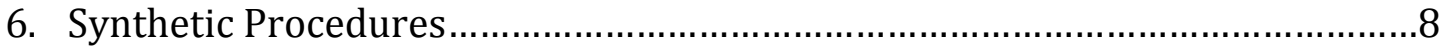

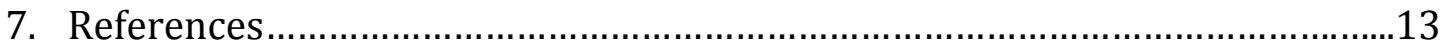

8. NMR Spectra of Boron Adducts and Reduction Products..............................14 


\section{General Considerations}

Isolation of the Weiss-Yoshida reagent (BAC Carbene- $\mathrm{LiBF}_{4}$ adduct) and addition to boranes was carried out under a dintrogen atmosphere in a 2001 issue IT Glovebox $\left(\mathrm{O}_{2}\right.$ levels typically $7 \mathrm{ppm}, \mathrm{H}_{2} \mathrm{O}$ levels typically $\left.15 \mathrm{ppm}\right)$ or oven dried Schlenk glassware. Hydrogenation reactions were carried out in scintillation vials equipped with magnetic stir bars inside a Parr bomb. The reactions were loaded into the Parr bomb, and the bomb was assembled inside the IT Glovebox. The reactor removed from the box and was purged by pressurizing to 300 psi with $\mathrm{H}_{2}$, and venting two times, before the final pressure was established. All other work-ups and reactions were carried out under ambient atmosphere in undried glassware. ${ }^{1} \mathrm{H},{ }^{13} \mathrm{C},{ }^{11} \mathrm{~B}$, and ${ }^{19} \mathrm{~F}$ NMR data were collected at $300 \mathrm{~K}$ on Bruker AV-500 or AV-300 NMR spectrometers. Chemical shifts are reported in parts per million downfield of $\mathrm{BF}_{3} \bullet \mathrm{Et}_{2} \mathrm{O}$ (for ${ }^{11} \mathrm{~B} \mathrm{NMR}$ ) and $\mathrm{CFCl}_{3}$ (for ${ }^{19} \mathrm{~F} \mathrm{NMR}$ ). ${ }^{1} \mathrm{H}$ NMR spectra are referenced to residual non deuterated $\mathrm{NMR}$ solvent $\left(\mathrm{CHCl}_{3}=7.26 \mathrm{ppm}\right) .{ }^{13} \mathrm{C}$ NMR spectra are referenced to the central $\mathrm{CDCl}_{3}$ peak $(77.0 \mathrm{ppm})$. Two ${ }^{13} \mathrm{C}$ resonances in compound 7 were not observed, despite prolonged acquisition time. Melting points were acquired using an Electrothermal ${ }^{\circledR}$ apparatus and are uncorrected. Mass spectrometric data were acquired by Mr. Xiao Feng (Mass Spectrometry Laboratory, Dalhousie University). IR Spectra were acquired on a Bruker Tensor 27 FTIR, on $\mathrm{NaCl}$ plates.

\section{Solvents}

Pentane for purification (ACS grade) was purchased from Fisher and used as received. Toluene and pentane for reactions were deoxygenated and dried by sparging with dinitrogen gas, followed by passage through a double-column solvent purification system purchased from mBraun Inc. The solvents were stored over dry $3 \AA$ Å molecular sieves in the glovebox.

Diethyl ether for purification (ACS grade) was purchased from Fisher and used as received. Diethyl ether for reactions was further distilled from a purple solution of benzophenone/sodium ketyl, and stored over dry $3 \AA$ molecular sieves in the glovebox.

Dichloromethane (ACS grade) was purchased from Fisher and used as received.

Deuterochloroform (Cambridge Isotopes) was stored over dry $3 \AA$ A molecular sieves, but otherwise used as received.

Trifluorotoluene (Anhydrous $>99 \%$ ) was purchased in a Sure/Seal ${ }^{\mathrm{TM}}$ container from Aldrich and cannula transferred onto dry $3 \AA$ molecular sieves for storage in the glovebox, but otherwise used as received. 


\section{Reagents}

3 Å Molecular Sieves were purchased from Aldrich, and dried at $200{ }^{\circ} \mathrm{C}$ at approximately 0.5 torr for 12 hours prior to use.

BAC Carbene Precursors 8a and 8b were prepared according to literature procedures, and purified by recrystallization from dichloromethane/diethyl ether.1,2

Borane-Dimethyl Sulfide Complex was purchased from Aldrich and used as received.

Boron Trifluoride Etherate was purchased from Fisher, and distilled under a nitrogen atmosphere into a storage bomb prior to use.

n-Butyllithium was purchased from Aldrich as a $2.5 \mathrm{M}$ solution in pentane and the concentration was verified by titration with 1,10-phenanthroline/butanol prior to use.

Celite ${ }^{\circledR} \mathbf{S}$ was purchased from Aldrich and used as received.

Hydrogen was purchased from Praxair as UHP (99.999\%) grade, and used as received.

Silica Gel (40-63 $\mu \mathrm{m}$, Silaflash, P60) was purchased from Silicycle, and used as received.

Sodium Borohydride was purchased from Aldrich and used as received.

Trityl BArFate was prepared according to literature procedures. ${ }^{3}$

Reduction Substrates: Acetophenone, anisaldehyde, cinnamaldehyde, 4cyanobenzaldehyde, and 2-naphthaldehyde were purchased from Aldrich, and used as received after purity was verified by ${ }^{1} \mathrm{H}$ NMR.

Imines 21, 23 and $\mathbf{2 5}$ were prepared by a 1:1 combination of the appropriate ketone and benzylamine in dichloromethane, in the presence of 1 equivalent of titanium ethoxide for 24 hours. The reactions were quenched by addition of aqueous $\mathrm{KOH}(15 \%)$, filtered onto $\mathrm{Na}_{2} \mathrm{SO}_{4}$, refiltered and concentrated. Purification was accomplished by taking up the obtained solids in warm pentane, and cooling the resulting clear pentane solutions of the imine to $-15^{\circ} \mathrm{C}$. The resulting crystals were collected by suction filtration and were dried for 12 hours in a vacuum desiccator at approximately 30 torr over $\mathrm{P}_{2} \mathrm{O}_{5}$ before being brought into the IT glovebox. Yields of imines were typically $>60 \%$ by this method. 


\section{Crystallographic Solution and Refinement Details}

Crystallographic data for 6 and 9 were obtained at $-100{ }^{\circ} \mathrm{C}$ on a Bruker D8/Apex II CCD diffractometer using microfocus source $\mathrm{Cu} \mathrm{K \alpha}(\lambda=1.54178 \AA \AA$ ) radiation, employing samples that were mounted in inert oil and transferred to a cold gas stream on the diffractometer. Crystallographic data for 12 were obtained at $-80{ }^{\circ} \mathrm{C}$ on a Bruker PLATFORM/Apex II CCD diffractometer using graphite-monochromated Mo K $\alpha(\lambda=0.71073 \AA)$ radiation, employing a sample that was mounted in inert oil and transferred to a cold gas stream on the diffractometer. Programs for diffractomer operation, data collection, data reduction and absorption correction were supplied by Bruker. Gaussian integration (face-indexed) was employed as the absorption correction method for $\mathbf{6 , 9}$ and 12. The structures of $\mathbf{6}$ and $\mathbf{9}$ were solved by use of intrinsic phasing methods, while $\mathbf{1 2}$ was solved by use of direct methods/ dual space procedures; all were refined by use of full-matrix least-squares procedures (on $F^{2}$ ) with $R_{1}$ based on $F_{0}^{2} \geq 2 \sigma\left(F_{0}^{2}\right)$. In the case of 9 , two crystallographically independent molecules with similar metrics were observed. Data for one is selected in the text. 


\section{ORTEPS}

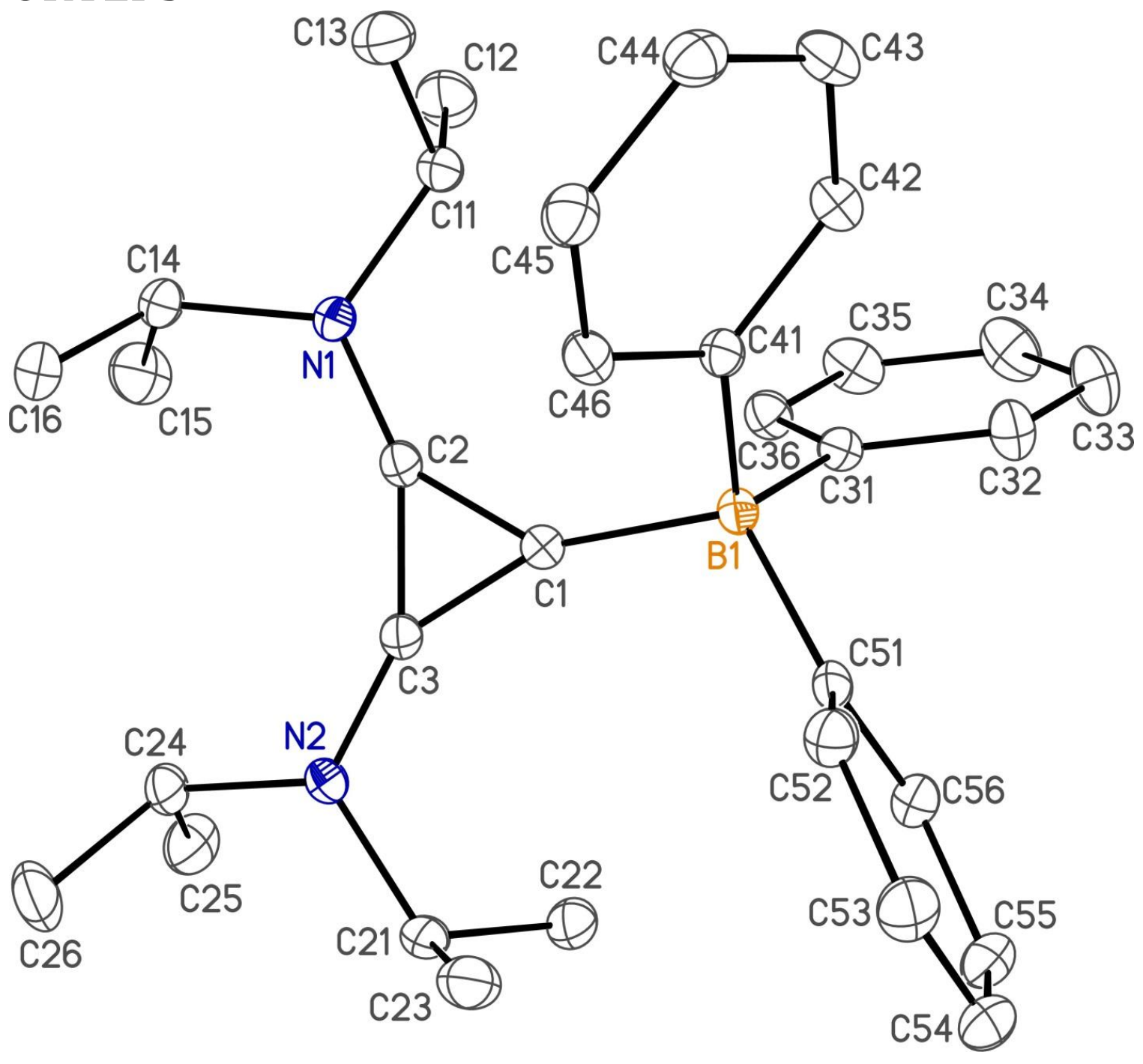




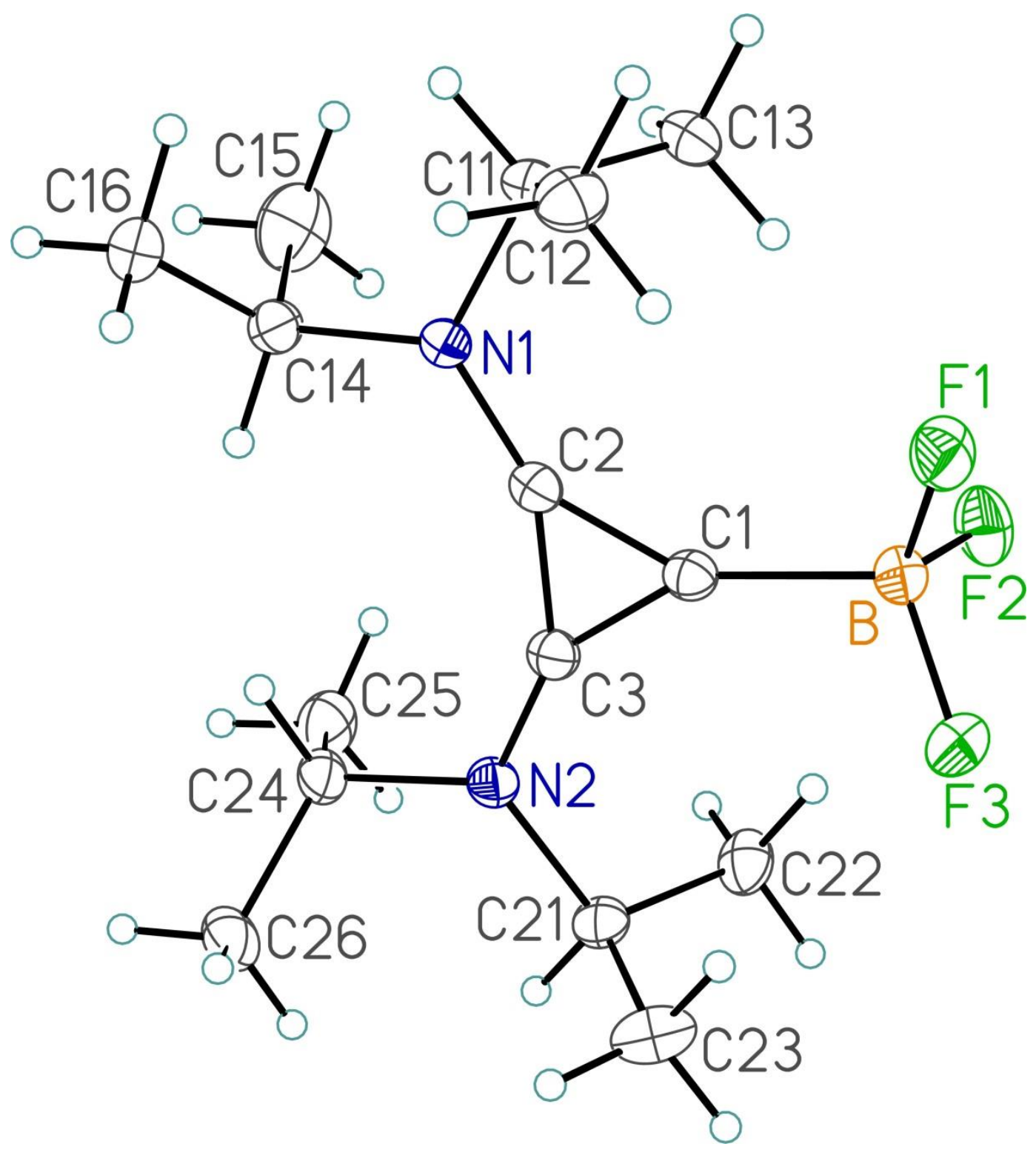




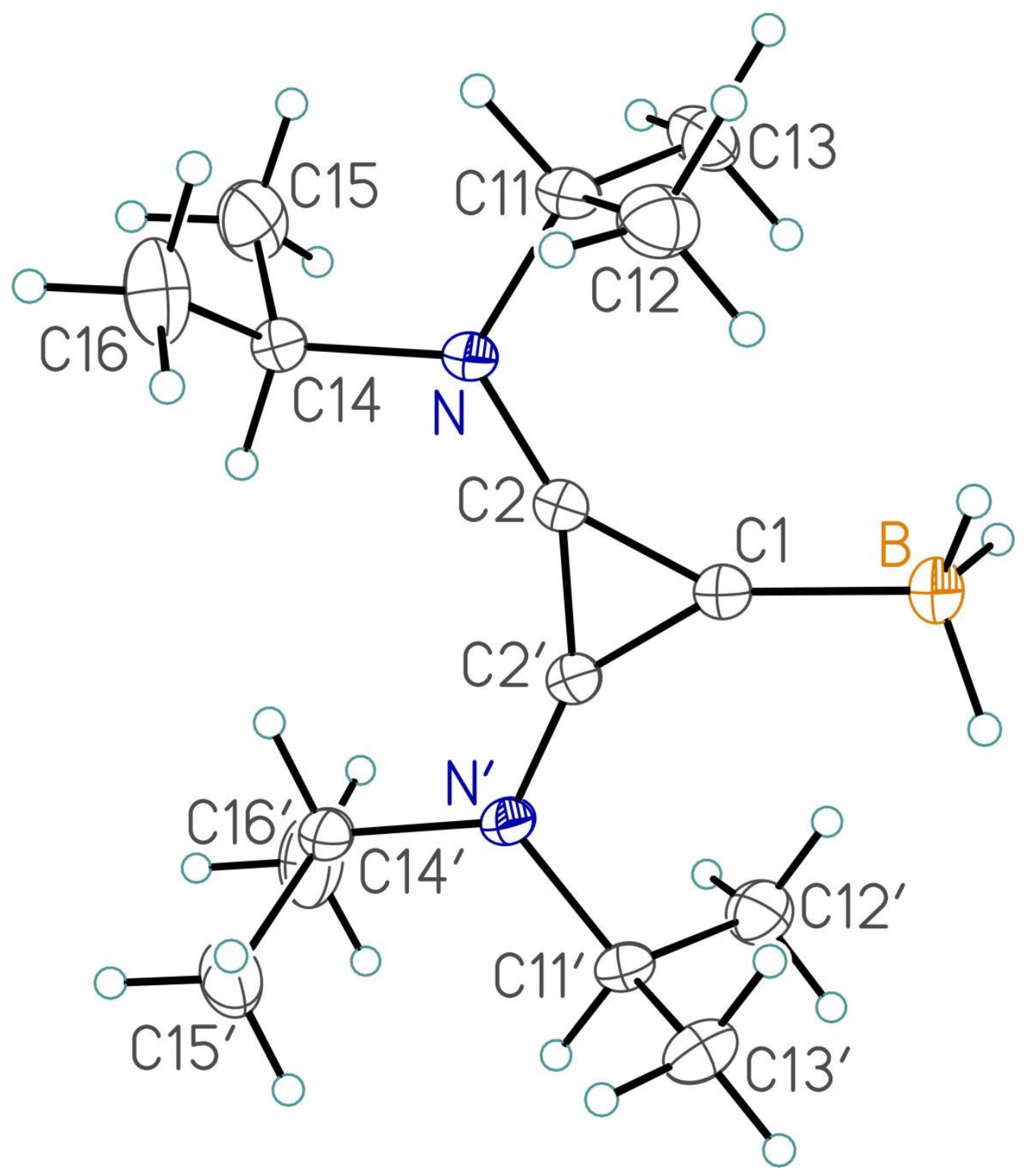




\section{Synthetic Procedures}

\section{Weiss-Yoshida Reagent (11)}

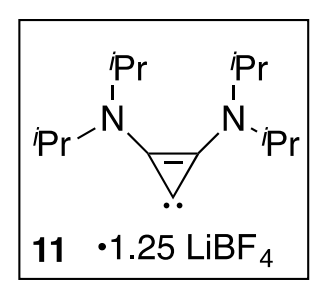

Two routes to $\mathbf{1 1}$ are presented below. Added lithium tetrafluoroborate in the deprotonation of $\mathbf{8 b}$ enhances the amount of material isolated. Compound $\mathbf{1 1}$ prepared by either route was found to give the same yield in replicate reactions with borane dimethyl sulfide complex for the formation of 6 .

\section{Preparation of 11 without $\mathrm{LiBF}_{4}$ addition:}

Compound $\mathbf{8 b}$ (375 mg, $1.16 \mathrm{mmol}, 1$ equiv) was added to an oven dried 4-dram vial equipped with a magnetic stir bar and suspended in diethyl ether ( $9 \mathrm{~mL}$ ). The slurry was cooled to $-25^{\circ} \mathrm{C}$ and a solution of $\mathrm{n}$-BuLi in pentane $(2.5 \mathrm{M}, 0.46 \mathrm{~mL}, 1.2 \mathrm{mmol})$ was added drop-wise with stirring. The reaction turned orange, briefly clarified, and then became turbid again with a beige colour. After 20 minutes, volatiles were removed in vacuo and the residue was triturated with pentane $(1 \mathrm{~mL})$. The resulting solid was then washed on a frit with pentane $(3 \times 4 \mathrm{~mL})$ and dried in vacuo to obtain BAC-Li as a white powder, (310 mg, $0.87 \mathrm{mmol}$, based on Bertrand's composition2: $353.5825 \mathrm{~g} / \mathrm{mol}$ BAC complex, 1 BAC: $1.25 \mathrm{LiBF}_{4}, 75 \%$ yield, maximum theoretical yield is $80 \%$ ). This white solid was stored at $-25^{\circ} \mathrm{C}$ and used without further purification.

\section{Preparation of 11 with $\mathrm{LiBF}_{4}$ addition:}

Compound $\mathbf{8 b}$ ( $1.00 \mathrm{~g}, 3.08 \mathrm{mmol}, 1$ equiv) was placed in a dry $50 \mathrm{~mL}$ Schlenk flask equipped with a magnetic stirbar. To the flask was added lithium tetrafluoroborate (72 mg, $0.77 \mathrm{mmol}, 0.25$ equiv), then $17 \mathrm{~mL}$ diethyl ether. The slurry was cooled to $25^{\circ} \mathrm{C}$ and a solution of $\mathrm{n}-\mathrm{BuLi}$ in pentane $(2.5 \mathrm{M}, 1.23 \mathrm{~mL}, 3.08 \mathrm{mmol}, 1$ equiv) was added dropwise with stirring. The reaction turned light orange, briefly clarified, and then became turbid again. After 25 minutes, volatiles were removed in vacuo and the residue was triturated with pentane $(5 \mathrm{~mL})$. The resulting solid was then washed on a frit with pentane $(3 \times 10 \mathrm{~mL})$ and dried in vacuo to obtain BAC-Li as a white powder, (1.01 g, $2.86 \mathrm{mmol}$, based on Bertrand's composition: 353.5825 g/mol BAC complex, 1 BAC: $1.25 \mathrm{LiBF}_{4}, 93 \%$ yield). This white solid was stored at $25^{\circ} \mathrm{C}$ and used without further purification.

\section{\{2,3-bis(diisopropylamino)cycloprop-2-en-1-ylium-1-yl\}triphenylborate (9)}

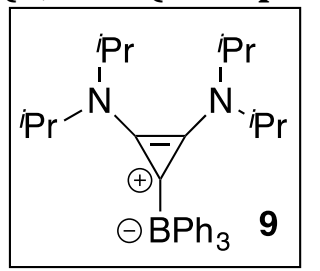

Compound 8a (300 mg, $0.539 \mathrm{mmol}$ ) was placed in a $10 \mathrm{~mL}$ round bottom flask equipped with a magnetic stir bar and suspended in $4 \mathrm{~mL}$ of toluene under nitrogen. To this suspension was added $\mathrm{NaBH}_{4}$ (20 mg, 0.539 mmol, 1 equiv), and the suspension was then allowed to heat at reflux for $17 \mathrm{~h}$. The mixture was allowed to cool, then was filtered over celite ${ }^{\circledR}$ which was washed with toluene $(3 \times 5 \mathrm{~mL})$. The volatiles were then removed from 
the washings and filtrate in vacuo to yield pure title compound $\mathbf{9}$ as a colourless solid (121 mg, 47\%). Crystals suitable for X-Ray analysis were grown by slow diffusion of pentane into a concentrated solution of 9 in toluene.

MP: $172-175^{\circ} \mathrm{C}$

IR (neat): 3128 (m), 2933 (m), 1857 (s), 1492 (s), 1208 (m), 1148 (m), 704 (s)

${ }^{1} \mathbf{H}\left(500 \mathbf{M H z} \mathbf{C D C l}_{3}\right): \delta 7.31(\mathrm{t}, 6 \mathrm{H}), 7.19(\mathrm{t}, 6 \mathrm{H}), 7.07(\mathrm{t}, 3 \mathrm{H}), 3.87(\mathrm{br} \mathrm{s}, 4 \mathrm{H}, \mathrm{CH})$, 1.08 (br s, $\left.24 \mathrm{H}, \mathrm{CH}_{3}\right)$.

${ }^{13} \mathrm{C}\left\{{ }^{1} \mathrm{H}\right\}\left(125.76 \mathbf{M H z} \mathbf{C D C l}_{3}\right): \delta 141.6,135.3,126.5,123.7,51.6,21.7$,

${ }^{11} \mathrm{~B}$ (160.46 $\mathrm{MHz}, \mathrm{CDCl}_{3}$ ): $\delta-9.4$ (br s).

HRMS(APCI): calcd for $\mathrm{C}_{33} \mathrm{H}_{44} \mathrm{BN}_{2}\left[\mathrm{M}+\mathrm{H}^{+}\right]$479.3592; Found: 479.3604 .

\section{\{2,3-bis(diisopropylamino)cycloprop-2-en-1-ylium-1-yl\}trifluoroborate (12)}

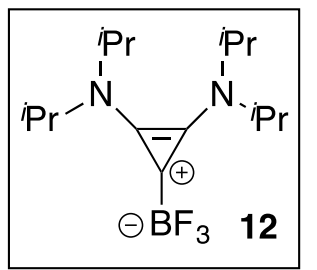

Compound 11 (53 mg, $0.15 \mathrm{mmol}$ ) was placed in an oven dried Schlenk tube equipped with a magnetic stir bar and dissolved in ether ( $3 \mathrm{~mL})$, then removed from the glove box. Under nitrogen, $\mathrm{BF}_{3} \bullet \mathrm{OEt}_{2}(0.020 \mathrm{~mL}, 0.16 \mathrm{mmol}, 1.1$ equiv) was added in one portion to the mixture. After 30 minutes the solution was transferred in air to a $25 \mathrm{~mL}$ round bottom flask, rinsing with dichloromethane $(5 \mathrm{~mL})$. The volatiles were removed in vacuo. The residue was dissolved in dichloromethane $(5 \mathrm{~mL})$ and filtered over celite ${ }^{\circledR}$, which was washed with dichloromethane ( $2 \times 2 \mathrm{~mL})$. Removal of volatiles from the combined washings and filtrate in vacuo yielded title compound 12 as a colourless solid (34 mg, 0.11 mmol, 74\%). Crystals suitable for X-Ray analysis were grown by slow diffusion of pentane into a concentrated solution of $\mathbf{1 2}$ in dichloromethane.

MP: Colour turns from colourless to brown from $188-190{ }^{\circ} \mathrm{C}$, melts at $200-206{ }^{\circ} \mathrm{C}$ IR (neat): 2976 (m), 1871 (m), 1518 (s), 1347(m), 1072 (m), 973 (m)

${ }^{1} \mathbf{H}\left(300 \mathbf{M H z} \mathbf{C D C l}_{3}\right.$ ): $\delta 3.89$ (ap sept, 4H, CH), 1.43 (d, $J=6.8 \mathrm{~Hz}, 12 \mathrm{H}, \mathrm{CH}_{3}$ ), 1.29 $\left(\mathrm{d}, J=6.8 \mathrm{~Hz}, 12 \mathrm{H}, \mathrm{CH}_{3}\right)$.

${ }^{13} \mathbf{C}\left\{{ }^{1} \mathbf{H}\right\}$ (75.47 $\left.\mathbf{M H z}, \mathbf{C D C l}_{3}\right): \delta 138.6,54.2,49.4,21.3,20.5$.

${ }^{19} \mathrm{~F}$ (282.4 MHz, $\mathbf{C D C l}_{3}$ ): $\delta-138.5$ (qt, $J=34 \mathrm{~Hz}$ ).

11B (96.3 $\left.\mathrm{MHz}, \mathrm{CDCl}_{3}\right): \delta-0.4(\mathrm{qt}, J=34 \mathrm{~Hz})$.

HRMS (ESI): calcd for $\mathrm{C}_{15} \mathrm{H}_{28} \mathrm{BF}_{3} \mathrm{~N}_{2} \mathrm{Na}\left[\mathrm{M}+\mathrm{Na}^{+}\right]$327.2190; Found: 327.2185.

\section{\{2,3-bis(diisopropylamino)cycloprop-2-en-1-ylium-1-yl\}trihydroborate (6)}

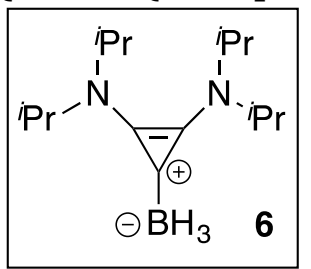

Compound 11 (532 mg, $1.50 \mathrm{mmol}$ ) was placed in an oven dried 4-dram vial equipped with a magnetic stir bar and suspended in toluene $(10 \mathrm{~mL})$. The solution was first cooled to $-25^{\circ} \mathrm{C}$ and then $\mathrm{BH}_{3} \bullet \mathrm{SMe}_{2}(1 \mathrm{M}$ in toluene, $1.61 \mathrm{~mL}, 1.61 \mathrm{mmol}, 1.07$ equiv) was added dropwise to the suspension. After 30 min the solution was filtered over celite $\AA$ and the celite $\AA$ was washed with dichloromethane $(3 \times 5 \mathrm{~mL})$. Volatiles were removed from the combined filtrate and 
washings in vacuo resulting in the title compound $\mathbf{5}$ as a beige solid (322 $\mathrm{mg}, 1.28$ mmol, 85\%). Colourless crystals suitable for X-Ray analysis were grown by slow diffusion of diethyl ether into a concentrated solution of $\mathbf{6}$ in benzene.

MP: Turns brown at $202^{\circ} \mathrm{C}$, decomposes to liquid at $205-209^{\circ} \mathrm{C}$

IR (neat): 3440 (br), 2976 (m), 2850 (w), 2286 (w), 1766 (m), 1493 (m), 1328 (m), $1158(\mathrm{~m})$

${ }^{1} \mathbf{H}\left(500 \mathrm{MHz}, \mathbf{C D C l}_{3}\right.$ ): $\delta 3.77$ (br s, $\left.4 \mathrm{H}, \mathrm{CH}\right), 1.34\left(\mathrm{br} \mathrm{s}, 24 \mathrm{H}, \mathrm{CH}_{3}\right), 1.65-0.80(\mathrm{~m}, 3 \mathrm{H}$, $\mathrm{BH}_{3}$, partially obscured by signal at 1.34 )

${ }^{13} \mathrm{C}\left\{{ }^{1} \mathrm{H}\right\}\left(125.76 \mathrm{MHz}, \mathrm{CDCl}_{3}\right): \delta 141.1,54.7,47.9,22.0,21.6$.

11B (160.46 MHz, $\mathrm{CDCl}_{3}$ ): $\delta-35.1$ (qt, $J=86 \mathrm{~Hz}$ ).

HRMS (APCI): calcd for $\mathrm{C}_{15} \mathrm{H}_{32} \mathrm{BN}_{2}$ [M + $\left.\mathrm{H}^{+}\right]$251.2653; Found: 251.2662

\{2,3-bis(diisopropylamino)cycloprop-2-en-1-ylium-1-yl\} dicyclohexylhydroborate (7)

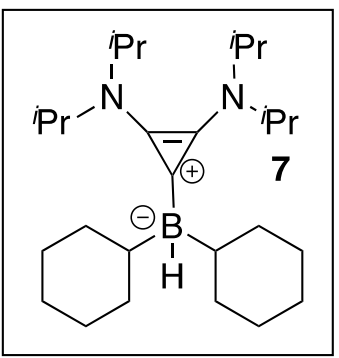

Compound 11 (375 mg, $1.06 \mathrm{mmol}$ ) was placed in an oven dried 4-dram vial equipped with a magnetic stir bar and dissolved in ether $(8 \mathrm{~mL})$. The solution was first cooled to -25 ${ }^{\circ} \mathrm{C}$ and then dicyclohexylborane (188 $\mathrm{mg}, 1.06 \mathrm{mmol}$ ) was added in one portion to the resulting suspension and stirred for $1 \mathrm{~h}$. Ether was then removed in-vacuo and the residue was taken up in dichloromethane $(4 \mathrm{~mL})$ and filtered on a fine frit. The collected solids were washed with dichloromethane $(3 \mathrm{x}$ $3 \mathrm{~mL}$ ) and volatiles removed in vacuo resulting in the title compound $\mathbf{7}$ as a beige solid (370 mg $0.893 \mathrm{mmol}$, 84\%).

MP: Turns orange at $102{ }^{\circ} \mathrm{C}$, decomposes to liquid at $104{ }^{\circ} \mathrm{C}$

${ }^{1} \mathbf{H}\left(300 \mathrm{MHz}, \mathbf{C D C l}_{3}\right): \delta 4.02$ (br s, $\left.4 \mathrm{H}, \mathrm{CH}\right), 1.79(\mathrm{~m}), 1.62(\mathrm{~m}), 1.32(\mathrm{~d}, J=6.8 \mathrm{~Hz}$, 24H, CH3), $1.14(\mathrm{~m}), 0.83(\mathrm{~m}), 0.45(\mathrm{br} \mathrm{t}, 2 \mathrm{H})$.

${ }^{13} \mathbf{C}\left\{{ }^{1} \mathbf{H}\right\}\left(125.76 \mathbf{~ M H z}, \mathbf{C D C l}_{3}\right): \delta 142.5,50.5,35.6,34.9,32.1-32.5$ (br), 29.8, 29.6, 28.3, 21.5.

11B (96.3 MHz, $\left.\mathrm{CDCl}_{3}\right): \delta-12.1(\mathrm{~d}, J=71 \mathrm{~Hz})$.

HRMS (APCI): calcd for $\mathrm{C}_{27} \mathrm{H}_{52} \mathrm{BN}_{2}$ [M + $\left.\mathrm{H}^{+}\right]$415.4218; Found: 415.4234

\section{General procedure for reduction with 6 in presence of $\mathrm{SiO}_{2}$ :}

Under air, compound 6 (63 mg, $0.25 \mathrm{mmol}$ ) was placed in a 4-dram vial equipped with magnetic stir bar and silica gel $(901 \mathrm{mg})$. To the solids was added an aldehyde or ketone $(0.5 \mathrm{mmol}, 2$ equiv.) and dichloromethane $(2.5 \mathrm{~mL}(0.2 \mathrm{M})$ or $1.6 \mathrm{~mL}$ $(0.3 \mathrm{M})$ ). Reaction progress was followed by TLC. The reaction was allowed to stir for the allotted time and then filtered through a porous frit. The silica was then washed with dichloromethane $(20 \mathrm{~mL})$ and volatiles were removed from the combined filtrates in vacuo. The resulting residue was taken up in $\mathrm{Et}_{2} \mathrm{O}(2 \mathrm{~mL})$ and filtered through a cotton plug, which was then washed with $\mathrm{Et}_{2} \mathrm{O}(2 \times 2 \mathrm{~mL})$. The 
$\mathrm{Et}_{2} \mathrm{O}$ was then removed in vacuo and an NMR spectrum was recorded in $\mathrm{CDCl}_{3}$. If impurities of aldehyde or ketone were remaning the resulting sample may be passed through a small plug of silica and eluted with ethyl acetate/ hexanes (1:5) to obtain product with ${ }^{1} \mathrm{H}$ NMR spectra corresponding to the reduced product.

4-cyanobenzyl alcohol (14a). Following the general procedure the reaction was completed after $1 \mathrm{~h}$ using a $0.2 \mathrm{M}$ solution and monitoring by TLC (ethyl acetate/ hexane 1:5) to afford the alcohol (58 $\mathrm{mg}, 87 \%$ ).

4-methoxybenzyl alcohol (16b). Following the general procedure the reaction was completed after $1 \mathrm{~h}$ using a $0.2 \mathrm{M}$ solution and monitoring by TLC (ethyl acetate/ hexane 1:5) to afford the alcohol (59 $\mathrm{mg}, 86 \%$ ).

2-napthalenemethanol (16). Following the general procedure the reaction was completed after $1 \mathrm{~h}$ using a $0.2 \mathrm{M}$ solution and monitoring by TLC (ethyl acetate/ hexane 3:7) to afford the alcohol (78 $\mathrm{mg}, 99 \%)$.

Cinnamyl alcohol (18).Following the general procedure the reaction was completed after $1.5 \mathrm{~h}$ using a $0.3 \mathrm{M}$ solution and monitoring by TLC (ethyl acetate/ hexane $1: 5$ ) to afford the alcohol (56 mg, 86\%) after purification with a small silica plug.

2-phenyl ethanol (14c). Following the general procedure the reaction was halted after $6 \mathrm{~h}$ using a $0.2 \mathrm{M}$ solution and monitoring by TLC (ethyl acetate/ hexane 1:5) to afford the alcohol in a 1.5:1 ratio with the starting material as observed by NMR integration.

\section{Formation of Borenium Cation 20 in situ from 7}

In a glovebox, compound 7 ( $15 \mathrm{mg} 0.036 \mathrm{mmol}$ ) and trityl barfate (40 $\mathrm{mg}, 0.036$ $\mathrm{mmol}$ ) were placed in an oven dried 1-dram vial equipped with a magnetic stir bar. To the solids was added $0.6 \mathrm{~mL}$ of $\mathrm{CDCl}_{3}$. The solution was stirred for $20 \mathrm{~min}$, then placed in a standard NMR tube. The cap was secured with Teflon tape, the tube was removed from the glovebox, and NMR spectra were acquired.

Diagnostic NMR Data:

${ }^{1} \mathbf{H}\left(300 \mathrm{MHz}, \mathbf{C D C l}_{3}\right): \delta 7.69$ (s, 8H, BArF), 7.52 (s, 4H, BArF), 7.11-7.30 (m, 15H, $\left.\mathrm{Ph}_{3} \mathrm{CH}\right), 5.55\left(\mathrm{~s}, 1 \mathrm{H}, \mathrm{Ph}_{3} \mathrm{CH}\right)$, 4.07-3.91 (m, $\left.2 \mathrm{H}, \mathrm{CH}\right), 3.76-3.62(\mathrm{~m}, 2 \mathrm{H}, \mathrm{CH}), 1.81$ $1.706(\mathrm{~m}), 1.34-1.12(\mathrm{~m}), 1.32\left(\mathrm{~d}, J=6.6 \mathrm{~Hz}, 24 \mathrm{H}, \mathrm{CH}_{3}\right)$

11B (96.3 MHz, $\left.\mathrm{CDCl}_{3}\right): \delta 81(\mathrm{~B}+),-6.6(\mathrm{BArF})$ 


\section{General Hydrogenation Procedure}

BAC-BCy $\mathrm{H} 7$ (10 mg, $0.024 \mathrm{mmol}, 10 \mathrm{~mol} \%$ ) and trityl BArfate 19 (27 mg, 0.24 $\mathrm{mmol}, 10 \mathrm{~mol} \%$ ) were placed in an oven dried 1 dram vial equipped with a magnetic stir bar. To this vial was added trifluorotoluene $(0.6 \mathrm{~mL})$ and the solution stirred for 5 minutes. Then the substrate was added as a solid, and the vial equipped with a septum and 16 gauge needle. This was placed into a Parr-bomb which was then assembled and removed from the glove box. In a fume hood, the bomb was placed on a stir plate, and purged twice by pressurizing to 20 atm of $\mathrm{H}_{2}$ followed by careful release. The bomb was subsequently pressurized to $20 \mathrm{~atm}$. After the allotted time, the bomb was carefully depressurized, disassembled, and the vials were removed. Solvent was removed in vacuo, conversion was ascertained by ${ }^{1} \mathrm{H}$ NMR (comparison of starting material and product, or triphenyl methane and product give values that agree). The amines were then subject to appropriate purification.

\section{Benzyl(1-phenethyl)amine}

Following the general procedure, acetophenone benzylimine (50 mg, $0.241 \mathrm{mmol}$ ) was added and stirred for $12 \mathrm{hr}$. Crude NMR indicated a 93\% conversion. The reaction mixture was purified by column chromatography on basic alumina (etherhexanes 15:85 then ethyl acetate-hexanes 1:1) to afford the title compound (28 mg, $56 \%$ isolated yield).

${ }^{1} \mathbf{H}\left(300 \mathrm{MHz}, \mathrm{CDCl}_{3}\right): \delta 7.36-7.20(\mathrm{~m}, 10 \mathrm{H}), 3.81(\mathrm{q}, J=6.8 \mathrm{~Hz}, 1 \mathrm{H}), 3.66(\mathrm{AB} \mathrm{d}$, $J=13.7 \mathrm{~Hz}, 1 \mathrm{H}), 3.59$ (AB d, $J=13.6 \mathrm{~Hz}, 1 \mathrm{H}) 1.61$ (br. s, $1 \mathrm{H}), 1.36$ (d, $J=6.6 \mathrm{~Hz}$ ).

\section{N-benzyl-1-aminoindan}

Following the general procedure indanone benzylimine (53 mg, $0.241 \mathrm{mmol}$ ) was added and stirred for $36 \mathrm{hr}$. Crude NMR indicated a $65 \%$ conversion. The reaction mixture was purified by column chromatography on silica gel (dichloromethane to elute unreacted imine, followed by $5 \% \mathrm{MeOH} / \mathrm{DCM}$ to elute product), affording the title compound ( $26 \mathrm{mg}$, $49 \%$ isolated yield).

${ }^{1} \mathbf{H}\left(300 \mathrm{MHz}, \mathrm{CDCl}_{3}\right): \delta$ 7.41-7.36 (m,3H), $7.32(\mathrm{t}, J=6.3 \mathrm{~Hz}, 2 \mathrm{H}), 7.26-7.17(\mathrm{~m}, 4 \mathrm{H})$, $4.29(\mathrm{t}, J=6.5 \mathrm{~Hz}, 1 \mathrm{H}), 3.93(\mathrm{AB} \mathrm{d}, J=13.1 \mathrm{~Hz}, 1 \mathrm{H}), 3.89(\mathrm{AB} \mathrm{d}, J=13.1 \mathrm{~Hz}, 1 \mathrm{H}), 3.09-$ $2.98(\mathrm{~m}, 1 \mathrm{H}), 2.84-2.78(\mathrm{~m}, 1 \mathrm{H}), 2.46-2.40(\mathrm{~m}, 1 \mathrm{H}), 1.92-1.86(\mathrm{~m}, 1 \mathrm{H}), 1.61$ (br. s, $1 \mathrm{H})$.

\section{N-4-methoxybenzyl(1-phenethyl)amine}

Following the general procedure, acetophenone 4-methoxybenzylimine $(58 \mathrm{mg}$, $0.241 \mathrm{mmol}$ ) was added and stirred for $12 \mathrm{hr}$. Crude NMR indicated a 83\% conversion. The reaction mixture was purified by dissolving in diethyl ether, adding 3 drops of concentrated sulfuric acid, extracting the ether with water, making the combined aqueous extracts basic, and extracting the amine with diethyl ether. Concentration in vacuo afforded the title compound (31 mg, $53 \%$ isolated yield) 
${ }_{1}^{1} \mathbf{H}\left(300 \mathrm{MHz}, \mathrm{CDCl}_{3}\right)$ ) 7.36-7.32 (m, 5H), 7.19,(ap. d, $J=8.6 \mathrm{~Hz}, 2 \mathrm{H}$ ), 6.84 (ap. d, $J=$ $8.6 \mathrm{~Hz}, 2 \mathrm{H}), 3.81-3.79(\mathrm{~m}, 1 \mathrm{H}), 3.79(\mathrm{~s}, 3 \mathrm{H}), 3.59(\mathrm{AB} \mathrm{d}, J=12.9 \mathrm{~Hz}, 1 \mathrm{H}), 3.53(\mathrm{AB} \mathrm{d}, J$ $=12.9 \mathrm{~Hz}, 1 \mathrm{H}) 1.58(\mathrm{br} \mathrm{s}, 1 \mathrm{H}), 1.36(\mathrm{~d}, J=6.6 \mathrm{~Hz}, 3 \mathrm{H})$.

\section{References}

(1) Lavallo, V.; Canac, Y.; Donnadieu, B.; Schoeller, W. W.; Bertrand, G. Science 2006, $312,722-724$.

(2) Lavallo, V.; Ishida, Y.; Donnadieu, B.; Bertrand, G. Angew. Chem. Int. Ed. 2006, 45, 6652-6655.

(3) Trityl BArF: Bahr, S. R.; Boudjouk, P. J. Org. Chem. 1992, 57, 5545-5547. Sodium BArF: Yakelis, N. A.; Bergman, R. G. Organometallics 2005, 24, 3579-3581. 


\section{NMR Spectra of Boron Adducts}

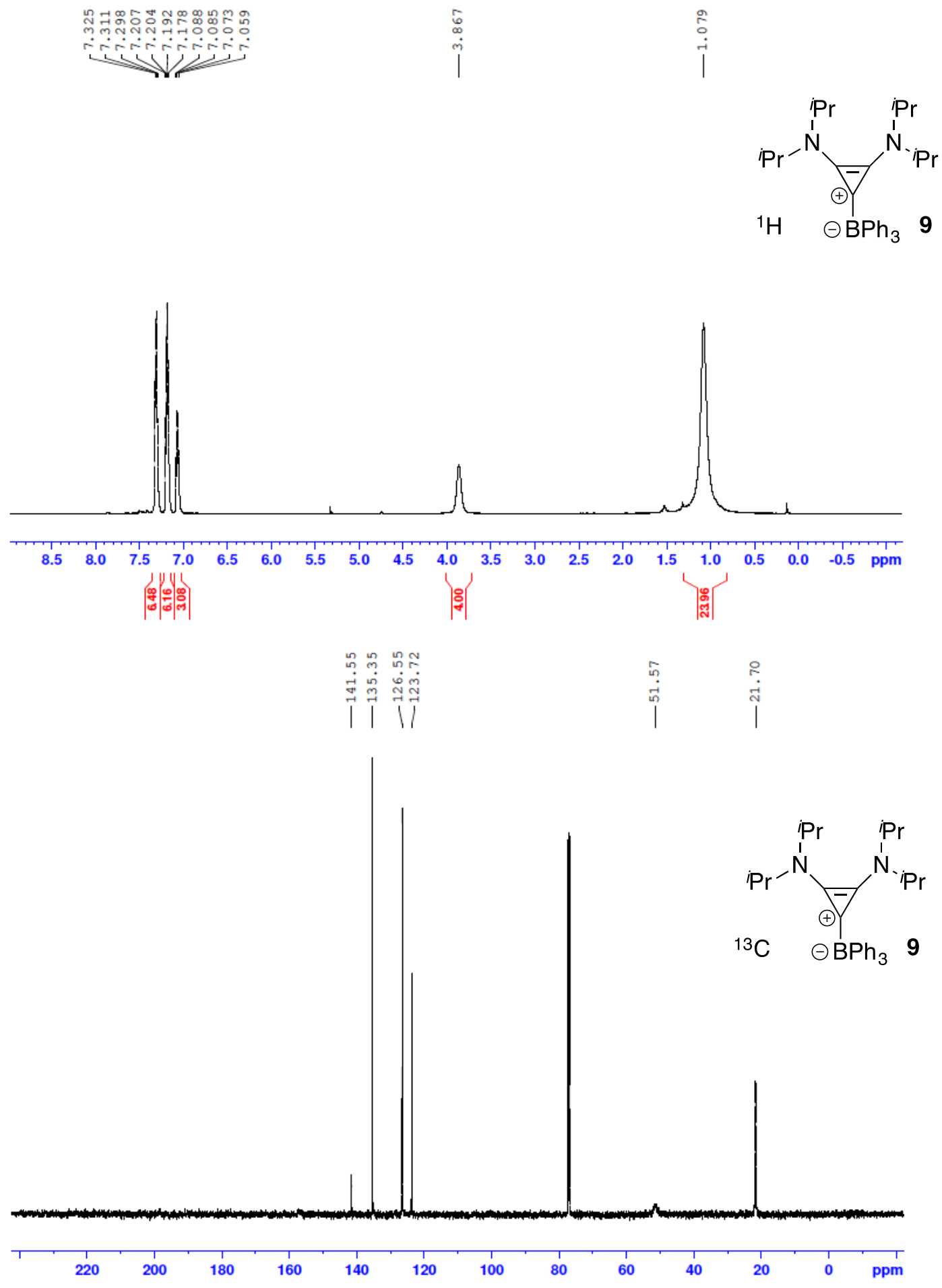




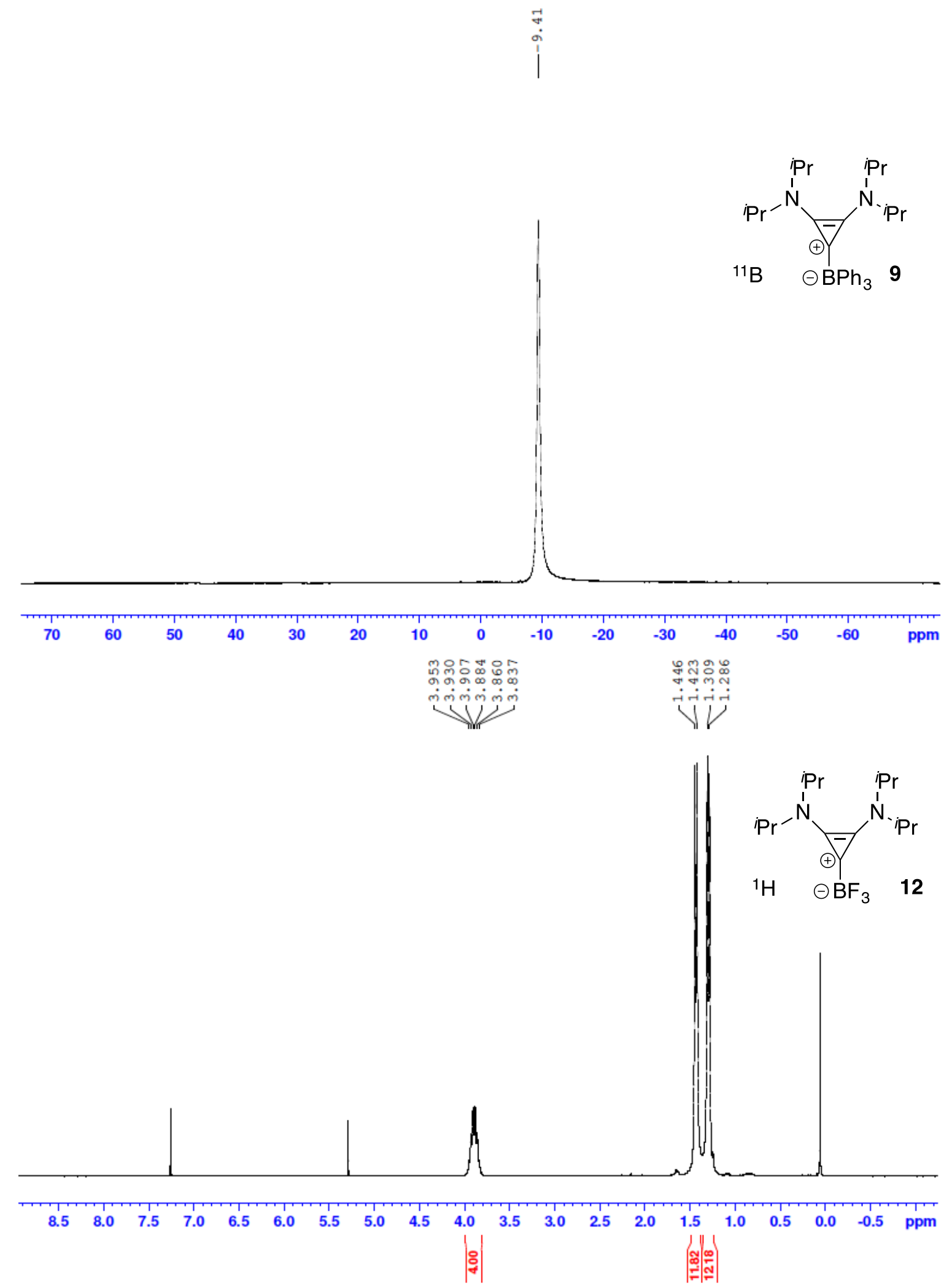




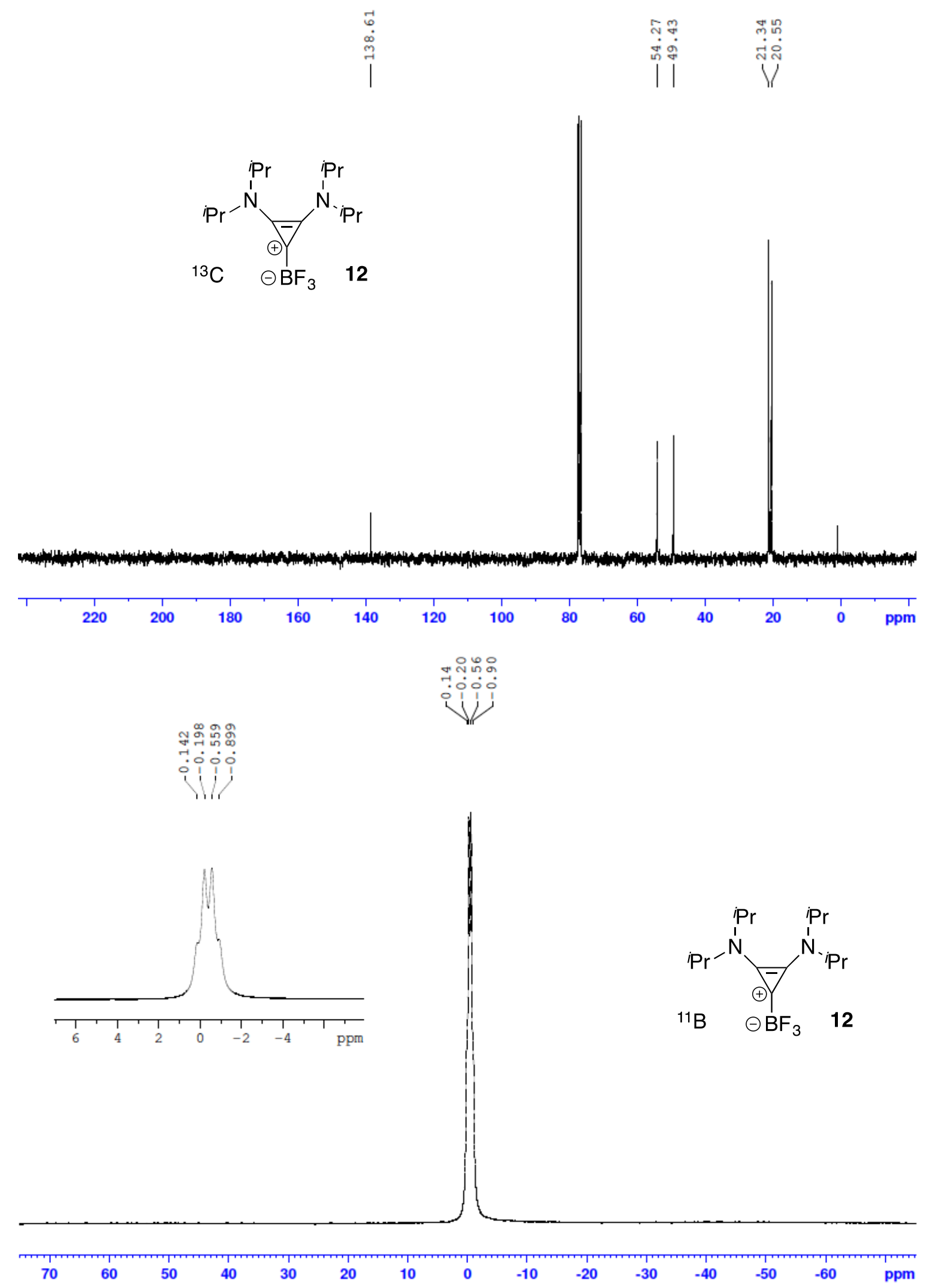




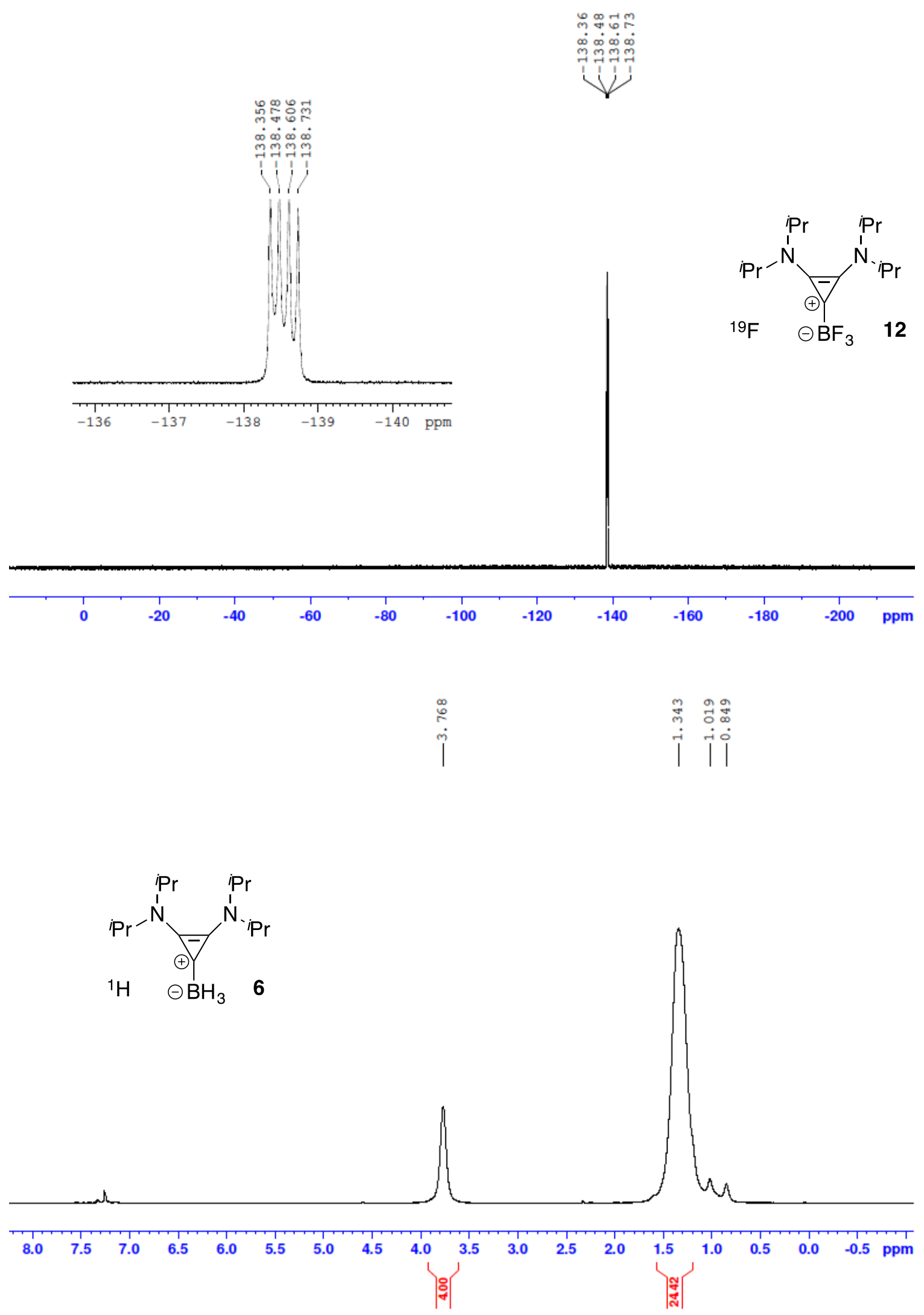




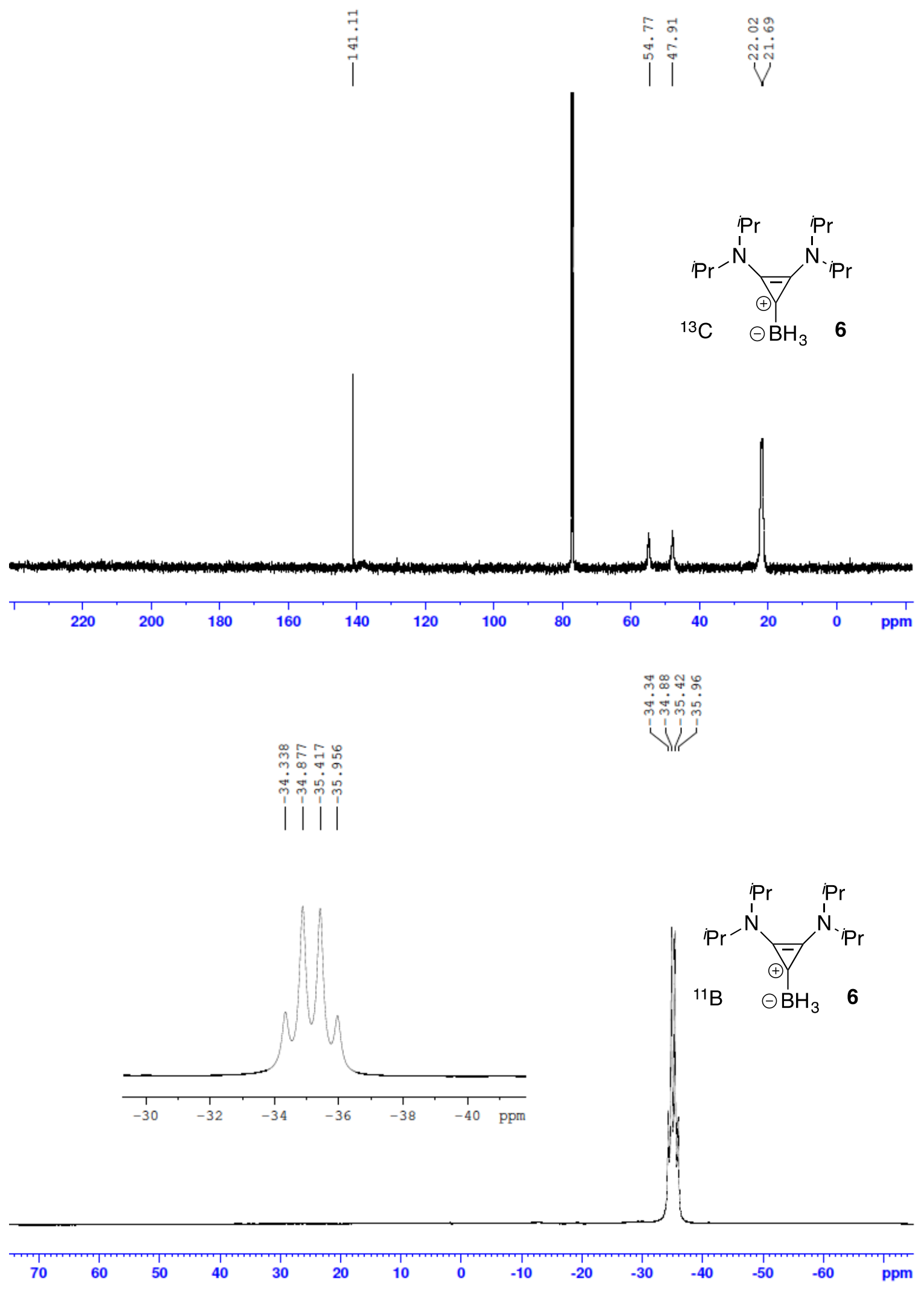



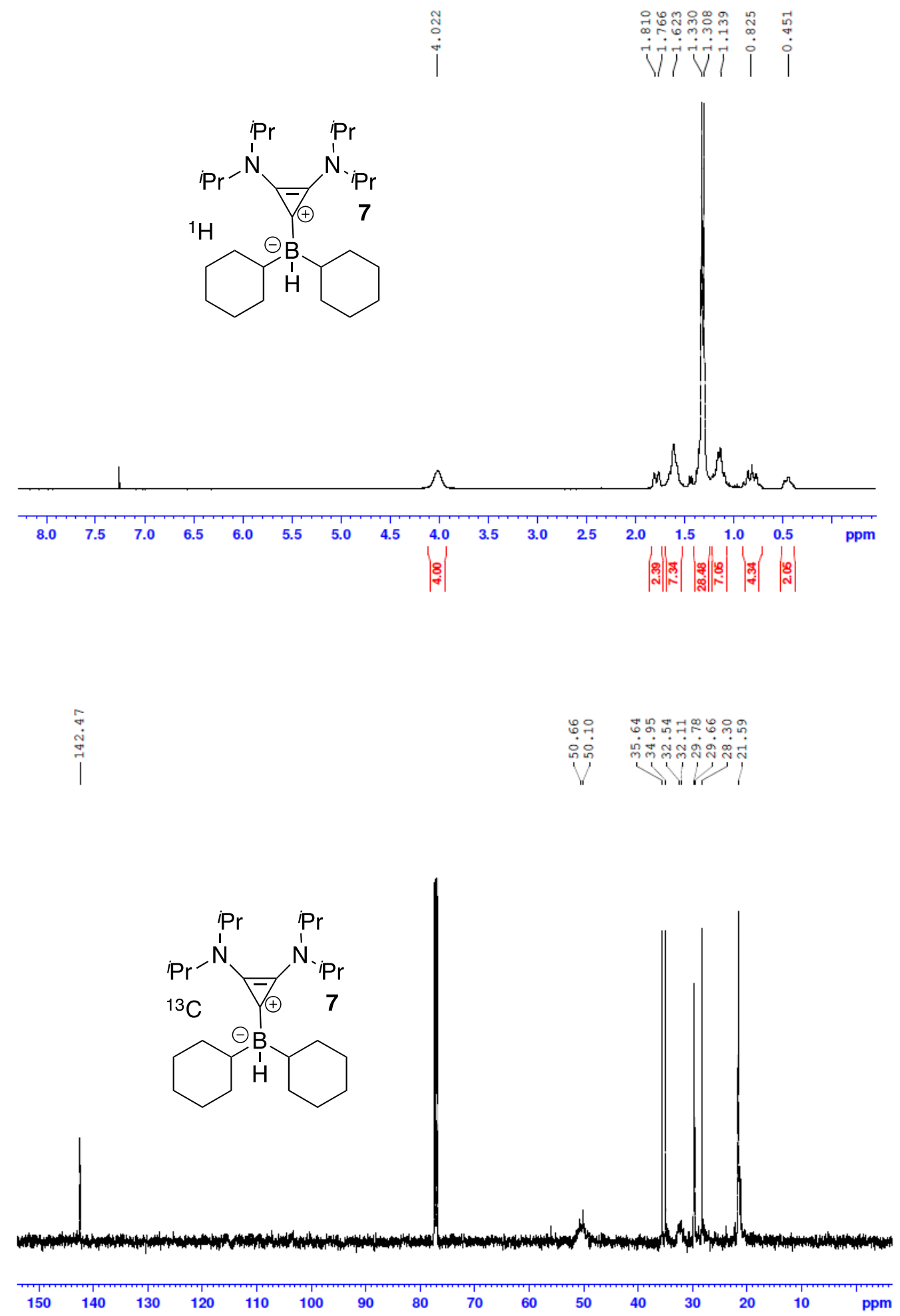


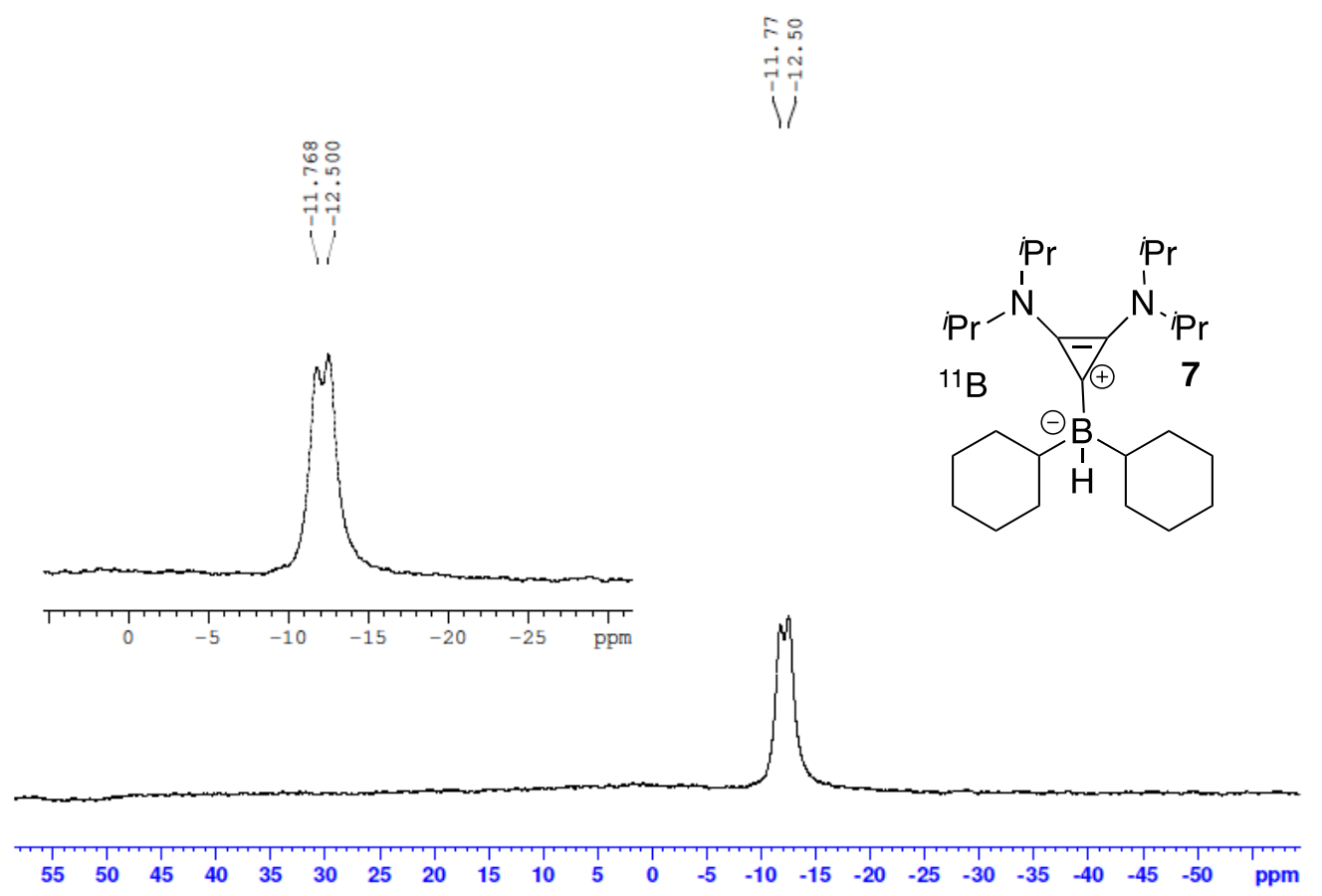



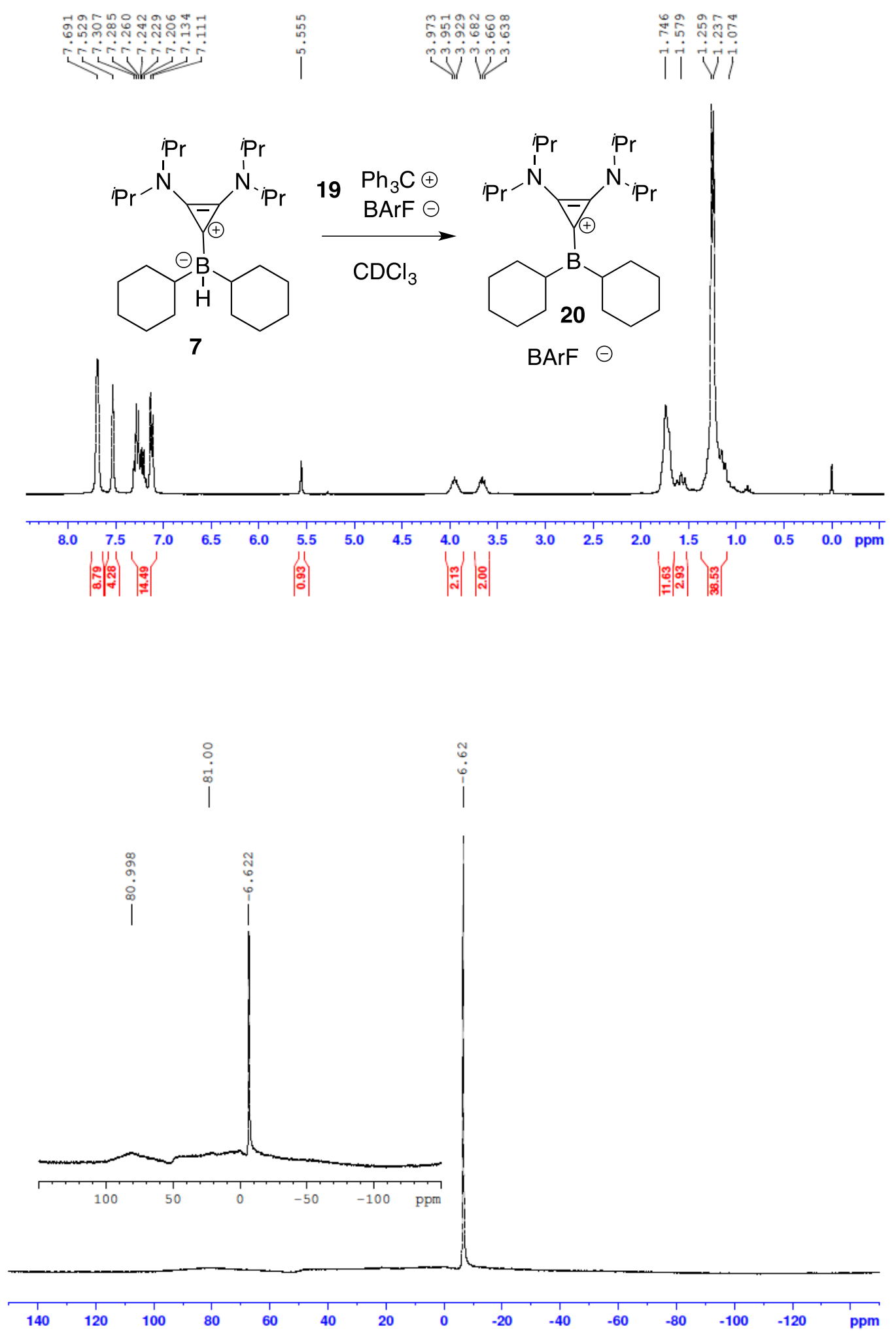

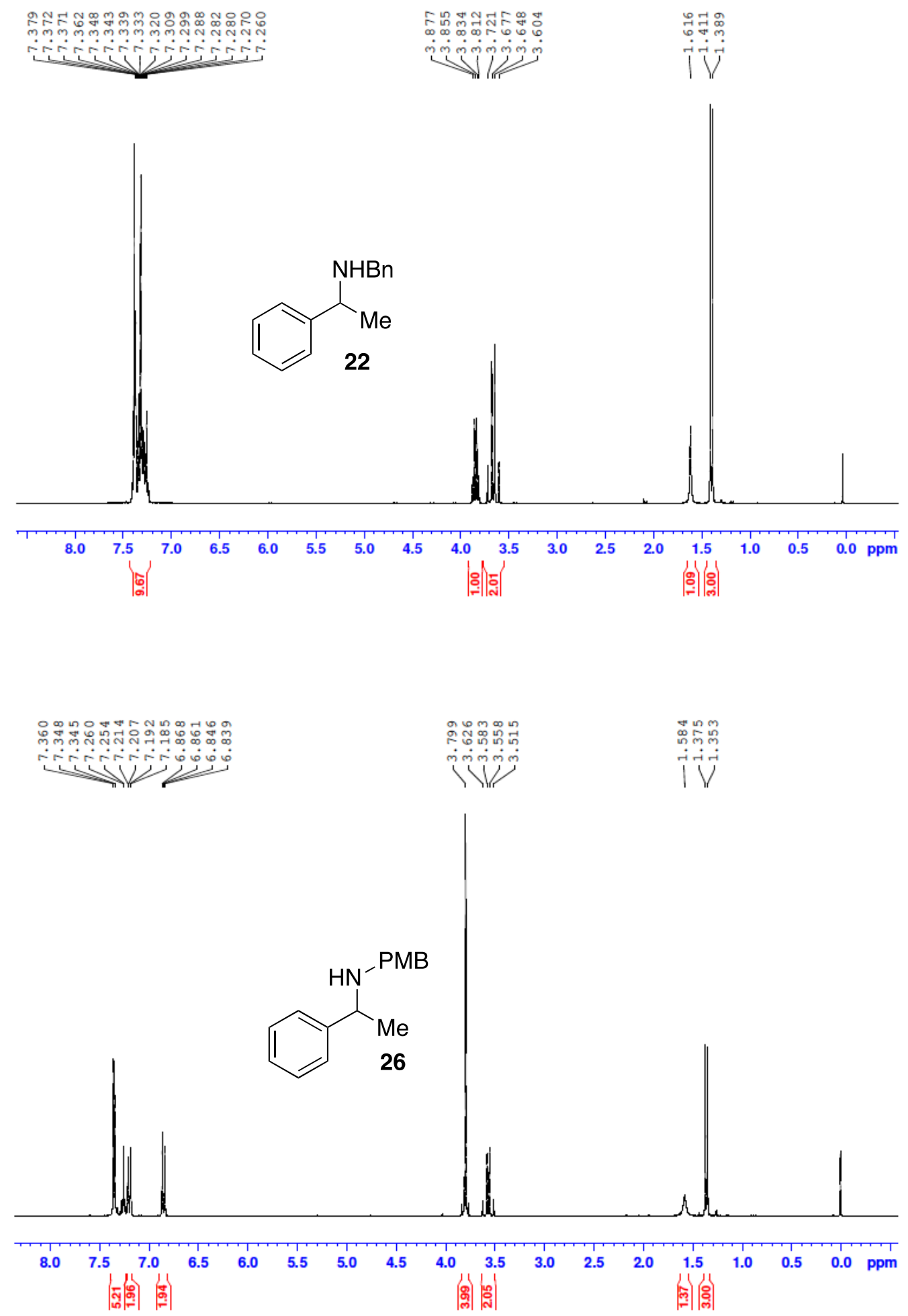


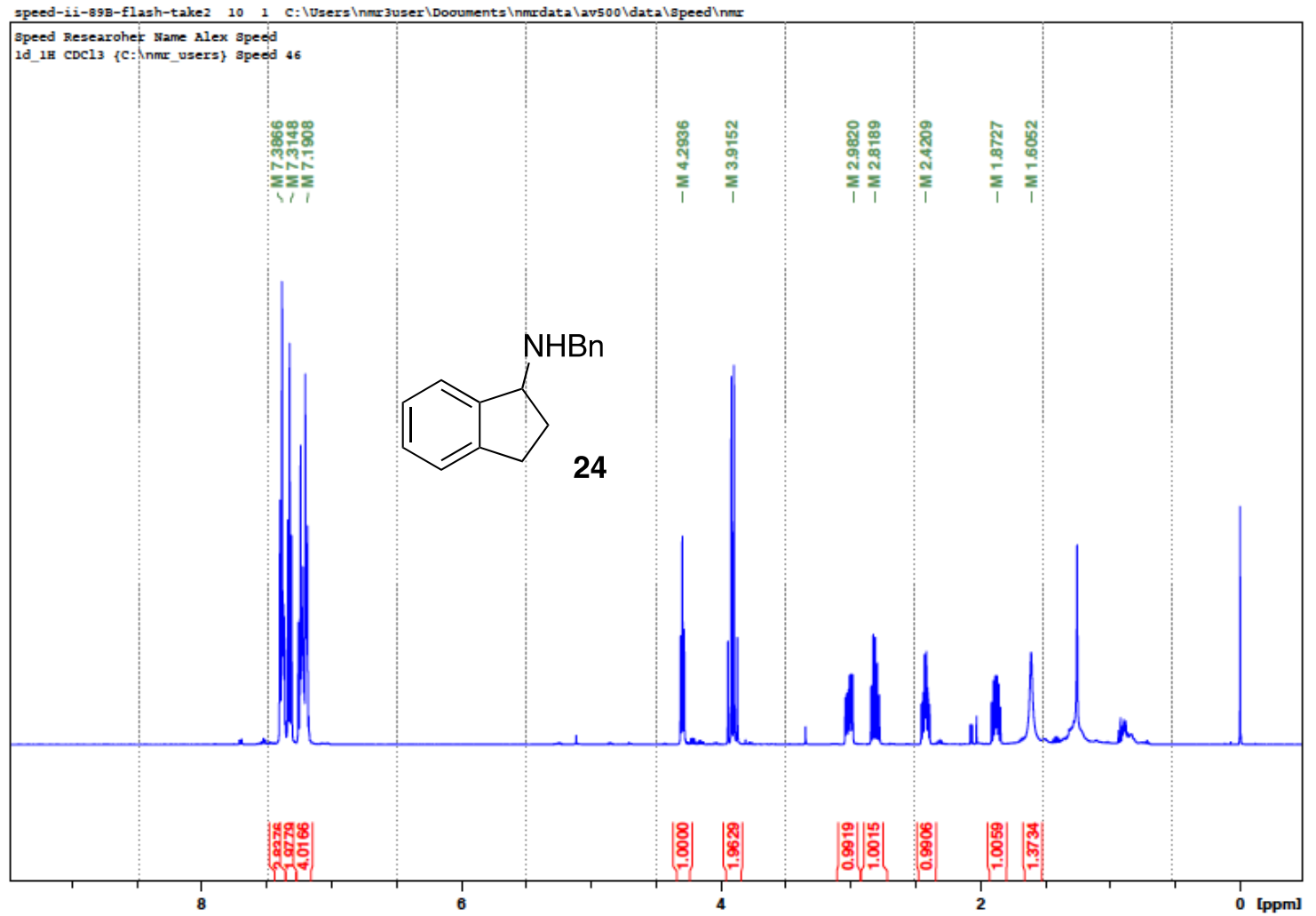

